REVISTA X, Curitiba, volume 14, n.6,p. $218-241,2019$.

\title{
(INTER)PERSONAL STATEMENTS: A DISCURSIVE ANALYSIS OF COLLEGE APPLICATION ESSAYS WRITTEN IN ENGLISH BY U.S. AMERICAN AND BRAZILIAN STUDENTS
}

\author{
(Inter)personal Statements: Uma Análise Discursiva de College Application Essays \\ Produzidos em Inglês por Estudantes Americanos e Brasileiros
}

José Orlando Cardoso do Monte Júnior (Universidade Federal do Paraná)

\begin{abstract}
The field of discourse analysis has produced extensive research on various aspects of genres that permeate everyday life as well as on the specialized discourses of academic and professional communities. Nevertheless, there is a dearth of studies on the personal statement, which, despite being a key genre of the admissions processes to globalized (and English languagedominated) institutions of higher education, remains unexplored in Brazilian educational culture. The present study addresses this gap by examining samples of this unique genre produced by US American and Brazilian students admitted to English-language universities. The analysis principally draws from Dominique Maingueneau's scholarship on the "scene" of a genre and the Bakhtin Circle's ideas on the social and generic nature of utterances. The main purpose is to compare and contrast rhetorical appeals to ethos and pathos made by both groups of students engaged in the high-stakes enterprise of writing about their values, beliefs, and goals with unknown readers/evaluators in mind. The results shed light on some of the linguistic and intercultural challenges that Brazilian students face when communicating in English within unfamiliar scenes of writing, the knowledge of which can shed light on ways to facilitate successful intercultural communication.
\end{abstract}

KEY WORDS: personal statement; ethos; pathos; genre; discourse analysis.

RESUMO: O campo da análise do discurso já produziu numerosas pesquisas sobre vários aspectos dos gêneros discursivos que permeiam a vida cotidiana, bem como sobre os discursos especializados produzidos por membros de comunidades acadêmicas e profissionais. Por outro lado, são escassos os estudos sobre o personal statement, um gênero-chave dos processos de admissão em instituições de ensino superior em países de língua inglesa que, no entanto, permanece inexplorado na cultura educacional brasileira. $\mathrm{O}$ presente estudo pretende diminuir essa lacuna ao examinar exemplares desse gênero tão peculiar produzidos por estudantes americanos e brasileiros admitidos em universidades de língua inglesa. A análise baseia-se principalmente no trabalho de Dominique Maingueneau sobre a cena enunciativa de um gênero e nas ideias do Círculo de Bakhtin sobre a natureza social dos gêneros enquanto enunciados. $\mathrm{O}$ principal objetivo da análise é comparar e contrastar as estratégias retóricas relacionadas às noções de ethos e pathos utilizadas por esses estudantes ao se engajarem na arriscada tarefa de escrever sobre seus valores, crenças e objetivos tendo leitores-avaliadores desconhecidos em mente. Os resultados lançam luz sobre alguns dos desafios linguísticos e (inter)culturais que estudantes brasileiros enfrentam ao se comunicarem em inglês no interior de cenas de escrita não- 
REVISTA X, Curitiba, volume 14, n.6,p. $218-241,2019$.

familiares, o que, por sua vez, pode lançar luz sobre formas de facilitar a comunicação intercultural.

PALAVRAS-CHAVE: personal statement; ethos; pathos; gênero discursivo; análise do discurso.

\section{INTRODUCTION}

Studies in academic discourse have mainly concentrated on the research article and its constituting sections, such as abstracts and introductions (e.g., SWALES, 1990; SAMRAJ, 2005). Nevertheless, little has been discussed about more "occluded genres" (see SWALES, 1996) such as the personal statement (henceforth PS), the most common of multiple types of college application essays. While a number of studies have examined PSs submitted to graduate programs (e.g., BROWN, 2005; DING, 2007), essays written for undergraduate admissions have received little attention. Perhaps this is a consequence of the hybrid status of a genre that "hardly seems academic: a deeply personal narrative written for a complete stranger with no clear standards of assessment" (WARREN, 2013, p. 45), which might make it a difficult genre to grasp, both theoretically and methodologically.

The writing of a PS becomes even more intriguingly unique when we consider the challenge that it poses to Brazilian students who wish to attend university abroad. These students need to meet the expectations of foreign admissions committees despite being even further from that "imagined community" (see KANNO; NORTON, 2003) than other "local" candidates who have built their values and goals within the same cultural framework as their readers/evaluators. Having a different socioeconomiccultural background and as speakers of English as an additional language, Brazilians (as other "international candidates") represent themselves through distinctive themes and styles, which take linguistic form in the specific rhetorical strategies that they use to write their way into higher education in an English-speaking academic setting.

In light of this thesis, this study aims to compare, contrast, and interpret rhetorical appeals to ethos and pathos appearing in PSs written by US American and Brazilian students admitted to universities in the USA. That being the case, in addition to drawing on the still-limited body of work in the PS genre, I will mainly base my analyses on two of the most prominent theoretical and methodological lines of inquiry that permeate the multifaceted genre research carried out in Brazil. The first is French 
REVISTA X, Curitiba, volume 14, n.6,p. $218-241,2019$.

discourse analyst Dominique Maingueneau's take on the Aristotelian concepts of ethos and pathos as rhetorical modes of persuasion and their effects on the assignment of genre-related roles and identities to writers and readers. The second is the Bakhtin Circle's influential ideas on language use as a discursive phenomenon embedded in the cultural-ideological nature of utterances and the productive relationship between language style and the constraints and affordances of speech genres. The analyses focus on the language choices that successful applicants make to convey credible images or discursive representations of themselves (ethos) while establishing rapport with their imagined addressees (pathos). To put it in Bakhtinian terms, the head comparative category for my analyses is addressivity, or an utterance's quality of being directed at a specific audience (BAKHTIN, 1986): I intend to identify and interpret how PS writers use interpersonal resources in the English language to relate to the perceived values, beliefs, and community- and culture-based expectations of university admissions committees. As the results of the study demonstrate, achieving this task poses different challenges to US Americans and Brazilians, though PSs from both groups share genremotivated rhetorical tools to garner acceptance into the academic community.

In what follows, I present the theoretical background of the study, which is followed by a discussion of the data collection method used and of results and conclusions elicited through the analyses.

\section{RELEVANT LITERATURE}

Even in the USA, where the PS is an essential component of applications for admission to higher education institutions, secondary school curricula lack sufficient focus on the explicit instruction of this genre (EARLY; DECOSTA-SMITH, 2011). This gap is even greater in Brazil, where university admission relies almost solely on standardized test scores. Such a quantitative assessment of student college-readiness threatens to undermine Brazilian students' participation in the academic community on an international and intercultural scale. Johns (2008) rightfully argues that enhancing students" "rhetorical flexibility" depends on having language education (including assessment) that allows for ample exposure to and analysis of the idiosyncrasies of the genres that they will need to produce to become integrated into academia, both locally and globally. As Bawarshi and Reiff (2010) explain, such pedagogy "promotes genre awareness and situates genre learning (thus teaching rhetorical flexibility), encouraging 
REVISTA X, Curitiba, volume 14, n.6,p. $218-241,2019$.

students to consider the complexity of genres and their varied realizations in real world contexts" (p. 208).

Paley (1996) argues that the PS challenges most college applicants with the first seriously consequential writing task of their lives. According to the author, such singular circumstances render the creation of a PS not only a "rite of passage" but also a "rhetorical paradox": the imperative of writing in a personal style conceals the need to project an image that matches the values and expectations of the target institution. As Paley asserts: "The applicant's autobiographical statement must [...] be 'of the right kind' for the admissions committee to unlock the gate to the university" (PALEY, 1996, p. 8990). Vidali (2007) corroborates the paradoxical nature of the PS: she investigated samples of the genre whose authors had openly discussed having learning disabilities, which Vidali considered a "dangerous discursive move" (VIDALI, 2007, p. 615), as it invited readers to consider whether and how the writer "may-or may not-'fit' in the larger university" (p. 616). Her claim offers an interesting perspective on the meanings that could emerge from the PSs written by Brazilian candidates to English-speaking universities that the present study examines. How do these students deal with their "outsider" status when writing about their formative paths and college-readiness with their implicit readers being unknown members of a foreign, imagined academic community? In the second part of the "Analysis and Discussion" section of this paper, I will tackle this issue by comparing the ethos-pathos dynamics of PSs written by Brazilian students with those written by US American ones.

The conclusions put forward by Paley and Vidali's studies confirm Warren's (2013) suspicions that "the college essay is a persuasive argument masquerading as personal narrative" (p. 49). Warren submitted PSs written by underprivileged minority high school students (who are particularly unfamiliar with postsecondary academic culture) to a group of admissions counselors and found that application essay prompts can be misleading, as they rarely mention the argumentation-driven nature of the assessment criteria. The participating counselors stated that they most frequently rejected candidates for an overuse of pure description and exposition. An example of Warren's data illustrating this misstep is provided in the following excerpt of a student's attempt to write about her grandfather's influence on her life:

I call him "poppy." He is a tall, big-bellied man with brown eyes and a shock of black hair. He only wears shirts with a pocket in front so he can carry pens and a toothpick, and he always wears suspenders to 
REVISTA X, Curitiba, volume 14, n.6,p. $218-241,2019$.

hold up his slightly baggy pants. I'm never sure what he's thinking because he is so adept at hiding his emotions, but when something needs to be said he doesn't hesitate to speak his mind. Maybe it's succinct, maybe it's a long lecture, but it always carries an important point.

The counselor reacted negatively to the writer's purely descriptive style, as she is not able to make a case for the impact of the person described on her journey to college. Indeed, and I would add that the essay also lacks the projection of an interpersonal connection between the writer's style of voice (her ethos) and her representation of the audience (pathos). In this sense, I agree with Warren's claim for the need for studies that offer "the sort of rhetorical analysis that students should apply to any writing task: learn as much as possible about the audience and its expectations, study the discourse conventions of the particular genre, and consider how to come across as knowledgeable and credible" (2013, p. 55).

"The audience and its expectations" and "to come across as knowledgeable and credible": these are very good descriptors of the challenges faced by PS writers, wherever they come from. They are also excellent definitions of what Aristotle, rhetoric and argumentation theorists (e.g., FIORIN, 2015; DITTRICH, 2008) and discourse analysts (e.g., MAINGUENEAU, 2008; AMOSSY, 2005) have called the pathos and ethos dimensions of discourse. Therefore, Warren's study points in the same direction as the theoretical-methodological path leading to the results of the analyses reported in this paper; they rely on the joint function of discourse-based representations of addressees/admissions officers (pathos) and of the writer/candidate (ethos) in defining effective stylistic traits for successful performances of the PS genre.

Maingueneau (1999, 2002) and Bakhtin (1986) explore the interplay between writers and readers in relation to the specific rhetorical situations within and from which discourse genres gain meaning and function. Both authors' definitions of genre offer a window into their views on language use as a complex maze of social practices that can only be properly understood via the context-based interaction patterns of a language. To Maingueneau, the notion of discourse genre "implies socio-historically constrained communication devices which are always changing and to which metaphors such as 'contract', 'ritual' and 'game' can be easily applied" (2002, p. 320). Maingueneau presents the following definition of genre as discourse analysts currently approach it:

For some decades, particularly under the influence of the ethnography of communication and of Bakhtin's ideas, the discourse genre has 
REVISTA X, Curitiba, volume 14, n.6,p. $218-241,2019$.

been used for describing the manifold sorts of utterances produced in society. Newspapers, talk shows on TV, transactions in shops, etc. are considered discourse genres; they can be indefinitely diversified, according to the degree of accuracy that discourse analysts are eager to obtain. They are characterized by criteria such as roles, purpose, medium and textual organization (MAINGUENEAU, 2002, p. 320).

By arguing that genres assign "roles" to language users, forging their identities while they engage in some sort of "contract" or "game," Maingueneau emphasizes the interactive nature of text production (both in speech and in writing). This connects his work with that of language philosopher Mikhail Bakhtin. The scope of this paper does not allow for a proper comprehensive presentation of the extraordinarily rich ideas that the Bakhtin Circle has instilled in language studies. Fortunately, however, the opening paragraph of Bakhtin's seminal article on genres (published in the English language in the late 1980s) provides an interesting summary not only of the entire (long) essay but also of the Bakhtinian view of language as a discursive reality:

All the diverse areas of human activity involve the use of language. Quite understandably, the nature and forms of this use are just as diverse as are the areas of human activity. This, of course, in no way disaffirms the national unity of language. Language is realized in the form of individual concrete utterances (oral and written) by participants in the various areas of human activity. These utterances reflect the specific conditions and goals of each such area not only through their content (thematic) and linguistic style, that is, the selection of the lexical, phraseological, and grammatical resources of the language, but above all through their compositional structure. All three of these aspects-thematic content, style, and compositional structure-are inseparably linked to the whole of the utterance and are equally determined by the specific nature of the particular sphere of communication. Each separate utterance is individual, of course, but each sphere in which language is used develops its own relatively stable types of these utterances. These we may call speech genres (BAKHTIN, 1986, p. 60).

Bakhtin's claim that genres and the interactions that they make possible reflect the areas or spheres of activity within which they occur has been highly influential. Scholars from numerous disciplines have developed their own theories of genre and verbal interaction by paying tribute to Bakhtin's work. Dominique Maingueneau is a good example of this productive dialogue — and an especially relevant one, considering the focus of the present paper on PSs. In Maingueneau's theory, genre production and interpretation happen within "scenes," a metaphor that mirrors Bakhtin's areas or spheres of human action. Maingueneau (1999) states that "addressees interpret discourses through the association of two scenes, two contexts: one (generic scene) is 
imposed by the genre, the other one (scenography) depends on particular discourses" (p. 191). Genre and scenography are important concepts for analyzing PSs. French discourse analysis approaches genres as communicative devices that link linguistic, social, and functional aspects of verbal interaction (MAINGUENEAU, 1999). In this vein, the generic scene establishes social goals and corresponding discursive patterns that largely motivate recurrent linguistic choices in texts of the same genre, which complements what Bakhtin (1986) refers to as the sociohistorical construction of a genre style. At the same time, with each single use of a genre, a writer can negotiate within the limits of the generic scene to forge an individual style and, by extension, convey an effective "voice" or discursive ethos: "written texts imply a "voice' that has a specific tone. Readers (from heterogeneous signs given by the text) shape a more or less definite figure of the speaker's 'body' that corresponds to the text" (MAINGUENEAU, 2002, p. 330). The choices of words, arguments, grammatical constructions, and many other semiotic devices convey a

representation of the speaker [or writer] that the addressee constructs across the production of discourse: therefore, [ethos] is a representation produced by discourse, it is not what the speaker says explicitly about himself, nor the representation of the speaker that the addressee may have independently of discourse. Using pragmatic terms, it could be said that ethos is 'implied' in discourse (MAINGUENEAU, 1999, p. 194).

In written communication, ethos guarantees adhesion and persuasion: "It gets the addressee to identify himself with the behavior of a body that is invested by historically specified values" (MAINGUENEAU, 1999, p. 195). This is due to the power of appropriate and effective choices made by the writer with an audiencesensitive purpose in mind: each genre corresponds to "a manner of speaking [or writing] that is too a manner of behaving, which depends on norms and representations of body in a given community" (MAINGUENEAU, 1999, p. 195).

Therefore, linguistic and discursive choices in writing allow for designing an ethos for a specific scene or situation (such as the admissions process of a given college or university). This is where the selection of a scenography comes into play. According to Maingueneau (2002),

Each $[\ldots]$ 'generic scene' [...] assigns parts to actors, prescribes the right place and the right moment, the medium, and the text superstructures for texts of a particular genre. But for many instituted genres another type of scene is implied: 'scenography', which results 
REVISTA X, Curitiba, volume 14, n.6,p. $218-241,2019$.

from the choice of discourse producers. Roughly speaking, the generic scene is part of the context, it is the very scene that the genre prescribes, whereas scenography is produced by the text. Thus, two texts belonging to the same generic scene may stage different scenographies. [...] For example, advertisements for shoes can employ a very wide range of scenographies: a woman in her bedroom phoning a girlfriend, a young boy describing his new shoes to his mother, etc. (p. 321-322).

The late Brazilian linguist Luiz Antônio Marcuschi (2010) offered an example that highlights communicative purpose (the social action that scenography is designed to produce) among a genre's defining features: “An advertisement [genre] may be in the form of a poem or a list of products on offer [scenography]; what counts is to promote the products and encourage the purchase by customers or users of that product [purpose]" (p. 35, the translation, from Brazilian Portuguese, is mine). Maingueneau further posits that "in a scenography are associated a certain representation of the speaker [or writer] responsible for [the] discourse [and] a certain representation of the addressee" $(1999, \mathrm{p}$. 192). For instance, when a college applicant decides to compose his or her PS as a letter, this epistolary scenography breaks with generic conventions and therefore establishes a specific ethos and relationship with the admissions committee, thus fulfilling (perhaps even more successfully) the purpose of the genre.

One level of genre characterization precisely concerns how writers' thematic, stylistic, and compositional choices correspond with ways of relating to their audiences (BAKHTIN, 1986). In an effective PS, the interconnection between ethos and pathos assigns complementary roles and discursive images to the interlocutors: on one hand, upon the ethos of a promising candidate advocating his alignment with the values of an institution of higher education, and on the other hand, upon an implied reader, from whom an active and responsive understanding is expected. In the specific context of an admissions process, this response is actually a decision-making action: approval is dependent on the reader's adherence to the candidate's discourse-based representation or to the values and beliefs that are revealed-or constructed-from how he or she presents his or her formative experiences, achievements, and goals. This means that a well-designed PS forges an interpersonal link between the writer's ethos and the gatekeepers of the intended college or university, who are members of the imagined community that inhabits the pathos dimension of the essay.

This paper investigates the ways in which college candidates of two different backgrounds can construct such a link: US American students applying to universities in 
REVISTA X, Curitiba, volume 14, n.6,p. $218-241,2019$.

their own country and Brazilian students applying to attend university abroad. To ensure the highest possible degree of reliability and validity, an initial corpus of 80 items was narrowed down to 30 PSs submitted to a single university. This methodological choice aimed at unifying the corpus, since all of the student writers shared the same knowledge and expectations (limited as they were) about the presumed readers of their application essays. In addition, the selected institution (a private university in the Mid-Atlantic region of the USA) offers a large selection of successful PSs submitted over the last four years on its website, along with comments from admissions officers. These two complementary corpora produced a satisfactory amount of data for analysis, considering the absence of quantitative parameters applied in this study.

Gathering PSs written by Brazilian students posed a greater challenge: none of the essays in the initial corpus fell under this category, and attempts made to obtain data from other institutions proved fruitless. Therefore, six PSs of Brazilians previously admitted to US American universities were collected from the Brazilian government website titled Estudar Fora ("Study Abroad" in English) ${ }^{1}$ to fulfill the study's objectives.

For reasons of space, this paper only presents excerpts of a limited number of the examined essays that concentrate some of the most relevant and pervasive evidence of the interpersonal and intercultural connections between ethos and pathos in the PS genre.

Before moving on to the analysis section of the paper, an additional word about the rationale behind the selection of the PSs that made it into the corpus is in order, especially in regards to the profile of the students who penned them. This paper presents partial results of a more comprehensive study that makes up my doctoral dissertation research. Within the scope of that bigger enterprise, many efforts have been made to extend the analyses to PSs produced by students from different linguistic and geographical backgrounds beyond the Brazilian and American contexts. Nevertheless, I have stablished communication with scholars and colleagues who are mostly concentrated in the USA, which has been a determining factor in the data collection process-especially considering how difficult it is to gain access to authentic examples of such an occluded genre as the PS, with its circulation and assessment criteria limited

1 "Estudar Fora is an initiative of the Estudar Foundation that helps young Brazilians achieve their dreams of studying abroad through digital content and a specialized training course." (https://www.estudarfora.org.br/, the translation is ours). 
REVISTA X, Curitiba, volume 14, n.6,p. $218-241,2019$.

to faculty and university staff. ${ }^{2}$ My collaboration partnerships have allowed me to muster limited yet relevant insider information about the process that PSs go through during the confined context of the admissions process, which is a fundamental aspect of genre analysis from a discursive sociolinguistic viewpoint. Furthermore, it is hereby acknowledged that investigating the production of the PS genre in the Brazil-USA axis finds its relevance in the great number of institutional initiatives that have been put forward to strengthen ties between the Brazilian and US American academic communities (such as the exchange grants offered by the Fulbright Commission, for example). Such highly monopolizing internationalization efforts have taken place in the wake of the historical Brazilian (and multinational) student flow to North American institutions of higher education. To be sure, it is highly desirable that scholarship interest veer toward other academic contexts outside the inner-circle countries of the English-language world, beyond the scope of their overwhelmingly powerful economic policies. At the same time, however, I believe it is equally important to keep investigating the linguistic and ideological underpinnings of discourse production among the immense student population that makes up the heterogeneous international community encompassed by American academia. This is imperative to further our understanding of the linguistic and social (in a word, discursive) phenomenon of intercultural communication. It is a small piece of a very large and troublesome puzzle that the present paper attempts to at least partially elucidate.

\section{ANALYSIS AND DISCUSSION}

\section{Interpersonal Statements: US Americans}

The excerpt below (from a PS titled "20 Questions") exemplifies the interplay between argument styles and rhetorical appeals in the construction of the genre's efficacy.

(PS1)

"Is it bigger than a breadbox?"

"Yes."

I have always been tall, decidedly tall. Yet, my curiosity has always surpassed my height. Starting at a young age, I would ask countless questions, from "How heavy is the Earth?" to "Where does rain come

\footnotetext{
${ }^{2}$ This is the reason for lack of personal information about the student writers of the selected texts, including their age, educational and cultural backgrounds, socioeconomic status, etc. Nonetheless, the discursive analyses presented here are based on textual and linguistic cues of ethos (an identity effect produced by language choices), which guarantees the reliability of the results.
} 
REVISTA X, Curitiba, volume 14, n.6,p. $218-241,2019$.

from?" My curiosity, displayed in questions like these, has truly defined me as a person and as a student. Therefore, it is not surprising that I became transfixed the first time I played 20Q (the electronic version of Twenty Questions).

[...]

"Does it strive to learn?"

"Yes."

I became determined to discover how 20Q guessed correctly. After some research, I discovered artificial intelligence, more specifically, artificial neural networks-systems which learn and improve themselves. This idea fascinated me. I wanted to learn more. I read avidly, seeking and absorbing as much information as I could. When given the opportunity years later, I signed up for the first computer programming class available to me. I found myself in an environment I loved. I would stay after class, go in during free periods, make my own apps.

[...]

"Does it think deeply?

"Yes."

So far, I have realized that thriving at Twenty Questions, just like life, is all about tenacity, rationality and interpersonal skills. I have found that, as in Twenty Questions, always succeeding is impossible; however, by persevering through difficulties and obstacles, favorable outcomes are often attainable. As I have become better at Twenty Questions, so too have I improved in many other aspects of my life. Nonetheless, I realize that I still have unbounded room to grow. And much like 20Q, I will continue to learn throughout my life and apply my knowledge to everything I do.

In emulating the game "Twenty Questions," the writer aligns himself with ideological principles associated with technological development and with the value placed by the modern American society on personal effort ( “... life is all about tenacity, rationality and interpersonal skills”; “... by persevering through difficulties and obstacles, favorable outcomes are often attainable”). Such line of reasoning largely delineates the character traits that underlie the constitution of this candidate's "voice" or discursive ethos. Furthermore, the writer designs and structures his essay to move it away from the usual narrative-like scenography of PSs: each paragraph simulates the answer to a question that embodies values and criteria used by admissions officers to evaluate potential candidates ("Does it strive to learn?"; "Is it driven?"; "Does it apply what it learns?"; "Does it attempt to better itself?"; "Does it think deeply?"). In addition, because "ethos is a dimension of scenography" (MAINGUENEAU, 1999, p. 195), these questions create a stimulating discourse frame in harmony with the very content and purpose of the PS genre. They promote an intertextual alignment of the essay with the 
REVISTA X, Curitiba, volume 14, n.6,p. $218-241,2019$.

scientific-technological ethos of the academic community while simulating a dialogue between the discursive representation of the writer (his ethos) and the presupposed expectations of the implicit recipient of the text. Brazilian discourse scholar Sírio Possenti (2002) maintains that this kind of ideological positioning positions the text (and the voice of its author) within a historical framework, that is, within a discourse that gives it meaning. According to Possenti, the quality of a piece of writing depends on its intertextual dialogue with the elements of a culture and with other discourses and beliefs, world knowledge, and a "social memory" (2002, p. 111), all of which create a density of meaning while signaling the writer's membership to a "cultural community" (p. 114).

The writer of PS1 also succeeds in highlighting the extent to which his personal experiences have contributed to revealing or developing skills akin to ideals and practices of the academic community that he wishes to join ("Starting at a young age, I would ask countless questions..."; “This idea fascinated me. I wanted to learn more."). This serves as another indication of his awareness of his audience and of its expectations and worldviews-that is, the pathos dimension of the argument. Just as important, however, is how he backs this line of argumentation with evidence, adding to the essay's logos, a rhetorical term for the logic behind an argument. An electronic game sparked his interest in artificial intelligence, which in turn motivated important choices and attitudes throughout his school career from elective courses taken ("I signed up for the first computer programming class available to me.") to his self-discipline ("I read avidly, seeking and absorbing as much information as I could.") to his proactive engagement in extracurricular activities ("I would stay after class, go in during free periods, make my own apps.").

Through how they are laid out in the essay, these choices-and the skills that they have nurtured-are discursively converted into character traits (an ethos) that largely justify the candidate's readiness for a future in higher education ("I realize that I still have unbounded room to grow. And much like 20Q, I will continue to learn throughout my life and apply my knowledge to everything I do."). Through the intertwining of the three modes of persuasion (ethos, pathos, and logos) in association with the scenography that they help legitimize, the writer of the above excerpt gained the adherence of the evaluators to his candidacy as revealed by their reaction to the text: 
REVISTA X, Curitiba, volume 14, n.6,p. $218-241,2019$.

We were impressed by the unique format [Name of candidate] chose to describe himself and the lessons learned through his interest in computer science. However, the essay's creative style succeeds due to the strength of its content. [Name of candidate] simulates electronic 20 questions to hook the reader's attention while effectively bridging his academic interests and future aspirations. The essay showcases his versatile interests, from computer science to basketball to political debate, as concrete examples that demonstrate his personal philosophy of 'practice and perseverance.' The essay successfully tells us about [Name of candidate]'s personality, academic and social interests, and future ambitions, showing us a competitive student who would thrive here.

The comment reveals the alignment between the candidate's driven and inventive ethos and the expectations of the admissions committee regarding prospective student members of their community ("a competitive student who would thrive here"). Furthermore, the excerpts that I have underlined above demonstrate a recurrent and most relevant line of argumentation used to fulfill the PS's communicative purpose. Writers of the vast majority of the (successful) PSs that I analyzed have outlined their paths to college by interweaving three rhetorical moves: (1) presenting transformative experiences accumulated both in personal life and throughout the school career (preferably those that bind these two spheres together); (2) discussing the effects of these experiences on their current interests, values, and beliefs; and (3) indicating how these events and circumstances, past and present, naturally point to a future self in tune with the expectations of the academic community. In doing so, a student's plan to enter university life is constructed, in and through discourse, as a logical and natural extension of what they already have done and become.

Let us now consider excerpts selected from PS2, in which the interplay of these three moves is even more apparent:

(PS2)

(1) The moment I realized that my Italian heritage was wholly a part of me was a rather insignificant one, yet to me is one of the most remarkable realizations of my life. The summer after my second year of Italian study, I was driving in my car, listening to a young trio of Italian teenagers, Il Volo, meaning "The Flight." As one of the tenors sang a solo, Ti voglio tanto bene, I realized that I could understand every word he was singing. [...]

(2) After that moment, I sought out all the Italian I could get my hands on: watching Cinema Paradiso and La Dolce Vita, absorbing phrases of the language I felt I could now call my own. Even better was that I felt confident enough in my skill that I could use it with my closest living Italian relative, my father's mother, la mia nonna. More than 
speaking the language, I discovered my family's past. In conversing with her and my father, I discovered that I will be only the third person in my paternal grandparents' family to attend college [...].

(3) Having now studied three full years of this language, I only want to consume more of it. [...] To me, the Italian language holds an essential connection to my past, but also a constant goal for the future. It is likely that I will never fully master the vernacular and colloquialisms, yet learning this language will stimulate me intellectually and culturally for life.

The student offers a very efficient narrative, constructing her ethos around her linguistic-cultural identity ("my Italian heritage was wholly a part of me"), projecting that identity into a future of knowledge development and personal growth ("learning this language will stimulate me intellectually and culturally for life"). The positive effect of this narrative thread on the reception of her PS is clear from the admissions committee's feedback:

Beyond being well-written and superbly descriptive, this essay really does a great job of illustrating [Name of student]'s appreciation for her heritage and the Italian language, as well as the desire to keep digging and learning more about it. She provides a clear story about how she arrived at her passion for Italian, how she pursues her passion currently, and how she plans on continuing to do so in the future. More importantly, she goes on to explain how it affects her view of the world.

The readers adhered to the candidate's ethos (her "appreciation for her heritage," "the desire to keep digging and learning," and "her view of the world") based on her rhetorical ability to interweave three stages of her formative narrative: (1) a critical incident in the past that launched her into a process of personal (trans)formation with repercussions for her intellectual enrichment; (2) an intervening period between that incident and the present, during which she sought opportunities to further develop her academic and intercultural skills; and (3) the projection of a future that would continue this formative process.

This line of reasoning proposes that the candidate's entry into the academic scene is not merely a possibility or desire, but simply the next stage of her already successful student career.

In the next example, the association between experiences of (trans)formation and a future in the academic world projects an ethos founded on cultural values and selfpromotion: 
(PS3)

Returning to Peru to visit my father's homeland, I was disturbed by the significant pollution, land degradation, unsustainable practices, and lack of clean water surrounding me. The memory of a destitute boy, surrounded by waste, consuming water from a filthy communal tap in a dilapidated shantytown of Lima, Peru still haunts me.

Exploration drives discovery. This pivotal experience formulated my passion and career objective: preserving the environment and protecting our resources. Since my discovery, I have never stopped preparing for a future in environmental engineering. I've immersed myself in rigorous classes of environmental science, chemistry, biology, math, physics, and geology. I have organized a "Walk for Water" to raise awareness of water conservation, worked extensively with the Chesapeake Bay Foundation and Youth Ocean Conservation Summit, and even received my first grant for a project designed to install a green roof, rain barrels, and a rain garden at my school. [...]

I want to collaborate with the top school of public health to address the risks of contaminated water, and develop efficient ways to conserve and purify water resources globally while preserving major ecosystems. I want to end land degradation in endangered and vulnerable biomes such as my father's homeland. I want to create alternatives to produce clean energy. I want to reduce the ecological footprint left by our species. [...] [Name of university] students don't submit themselves to demanding internships or research due to requirement; they yearn from a deeper understanding of what is at hand. That is who I am: self-driven and determined to go beyond what is necessary.

The underlined parts evidence the writer's awareness of the persuasive effects produced by cooperation between her past and present achievements in the projection of a feasible future as an environmental engineer. The narrative thread (a visit to her father's homeland leading to her environmental awareness and finally to her career plan) delineates her entry into a life dedicated to academic research and practice as a logical and natural development of a process initiated well before the actual beginning of her college experience.

In the third paragraph of the excerpt above, the student makes a direct reference to the department of the university that she is applying for: "I want to collaborate with the top school of public health..." With this she demonstrates her auspicious knowledge of the rhetorical situation in which she writes: she is tailoring her PS to the specific expectations of a particular institution (WARREN, 2013, p. 55). In doing so, she bridges the values that form her identity (and her discursive ethos) with the values of an academic community that would judge her suitability to its institutional standards 
REVISTA X, Curitiba, volume 14, n.6,p. $218-241,2019$.

("That is who I am"). This is a good example of a writer's awareness of the "active responsive understanding" (BAKHTIN, 1986) that her discourse is supposed to produce in the addressee. Maingueneau (1999, p. 195) explains the argumentative effect of this audience-sensitivity: "One of the reasons why discourse can persuade is that it gets the addressee to identify himself with the behavior of a body that is invested by historically specified values."

Feedback from the admissions committee on PS3 confirms the effectiveness of the writer's pursuit of a two-way street between ethos and pathos:

This essay does a great job of providing background on [Name of candidate]'s interest in environmental engineering and explaining why she wants to pursue the area as an undergraduate here. What stood out the most to us was [Name of candidate]'s ability to connect with the way students learn at [Name of university] in a meaningful way by relating it to her own interests and passions. We could tell she has thought about why [Name of university] is where she wants to pursue her intellectual passion.

It is meaningful how the admissions committee values the emphasis placed by the student on the bond between her aspirations and the university's culture. They even mention this twice: “... explaining why she wants to pursue the area as an undergraduate here"; "... she has thought about why [Name of university] is where she wants to pursue her intellectual passion." The expressions shown in bold indicate the importance that the readers have placed on the candidate presenting evidence for such a bond rather than merely expressing her desire to join that particular university.

\section{Intercultural Statements: Brazilians}

According to the Open Doors Report on International Education Exchange ${ }^{3}$ prepared by the Institute of International Education with support from the United States Department of State, there were almost 2 million international students in the USA in the 2017-2018 academic year, a record. Brazilians accounted for 14,620 of these students, representing an 11.7 percent increase from the previous academic year. More than half of these students were undergraduates, and of this amount, more than 80 percent supported themselves with personal financial resources. This indicates that Brazilian public school graduates did not represent a significant share of these migrant

\footnotetext{
${ }^{3}$ Available at: https://www.iie.org/Research-and-Insights/OpenDoors/Data/International-Students. Accessed on 15/05/2019.
} 
REVISTA X, Curitiba, volume 14, n.6,p. $218-241,2019$.

students. However, what puts most of these students at a disadvantage goes beyond their socioeconomic status within Brazilian society: their lack of command of the English language and even more importantly of high-stakes gatekeeping genres such as the PS make it all the more difficult for Brazilian public high school students to access higher education in English-speaking foreign institutions.

Nevertheless, a few Brazilians somehow manage to overcome this barrier and mostly those who have received full scholarships to study in private schools. In this section, we turn to two PSs produced by such Brazilian students to examine how their uses of rhetorical appeals match or diverge from those identified in essays written by US American students in the previous section.

The excerpt below is the opening paragraph of our first example (the italics are mine). Let us first observe how the essay's scenography defines the social (discursive) space in which the writer's ethos has its origin:

\section{(PS4')}

It was one of those hot Friday afternoons where nothing was out of the ordinary. Coming from school, I got off at my bus stop and began to walk home. As I walked along the BR-040 highway, I started to identify my neighborhood by its hodgepodge of colors. Some houses were painted green, yellow, or blue while others were left with their crumbling bricks exposed. This rainbow of colors amalgamated with a plethora of TV antennas and energy cables that had sprung up around the community like mushrooms, creating a direct contrast with the harmony of manicured lawns and white mansions of the noble neighborhoods beside the one where I live. While climbing the sinuous streets of my community, an aroma of rice and beans filled my nostrils. Sadly, this enticing aroma of a home-cooked meal was overpowered by a pungent smell of marijuana, bringing me back to the harsh reality of the pervasiveness of drug trafficking and violence among youth in the community where I live. Unfortunately, this reality is also pervasive amongst thousands of other peripheral neighborhoods (low-income regions on the outskirts of major cities) throughout Brazil.

The construction of this writer's ethos is associated with an ethnographic scenography, which reads almost as a topographical description of "my neighborhood," "my community," and "the community where I live." By referring to his place of residence with the word 'community' in a PS addressed to a presumably American reader, this Brazilian student faced a challenge of both linguistic and cultural nature. In Brazilian society, the expression '(needy) community' (comunidade carente in Portuguese) has been consolidated as a euphemism for the Portuguese noun 'favela,' 
REVISTA X, Curitiba, volume 14, n.6,p. $218-241,2019$.

which in certain contexts and situations can activate unwanted meanings (and identities) both for the place designated and for its inhabitants.

Now, the writer's description of his "community" corresponds to imagery often associated with Brazilian favelas. However, meanings associated with the word 'community' in English do not necessarily include the euphemistic use that has become commonplace in Brazil. The writer of the excerpt above is aware of this and shapes his discourse to prevent a lack of semantic clarity of the term 'community' from getting in the way of his line of argumentation. To this end, he not only substitutes this word for the expression 'peripheral neighborhood' but also includes a parenthesis to explain to his (American) reader what specific environment he is talking about: "[...] other peripheral neighborhoods (low-income regions on the outskirts of major cities) throughout Brazil."

In Hyland's (2004, 2005) "metadiscourse" model, explanatory comments such as this are classified as code glosses which "supply additional information, by rephrasing, explaining or elaborating what has been said, to ensure the reader is able to recover the writer's intended meaning" (HYLAND, 2005, p. 52). Hyland explains that metadiscourse includes a great number of linguistic features that a writer adds to a text in order to build a collaborative relationship with the addressee. Such constructions as glosses and footnotes (in addition to hedges, attitude markers, questions, and reader pronouns, to name just a few) "help relate a text to its context by assisting readers to connect, organize, and interpret material [...] with regard to the understanding and values of a particular discourse community" (HYLAND, 2004, p. 157). As an international candidate for an US American university, the writer of the excerpt above faces the high-stakes challenge of discussing his local community's socioeconomic reality without assuming his (foreign) reader's familiarity with the idiosyncrasies of Brazilian society or with the Brazilian Portuguese language. By including metadiscursive language in his PS, the student transforms "what might otherwise be a dry or difficult text into coherent, reader-friendly prose" (HYLAND, 2004, p. 157). Furthermore, this kind of verbal behavior contributes to the ethos of the text, as it also helps the writer to "convey his or her personality, credibility, audience-sensitivity and relationship to the message" (HYLAND, 2004, p. 157).

In addition to having successfully dealt with these linguistic and intercultural issues, the writer has also managed to meet the overall communicative purpose of the 
REVISTA X, Curitiba, volume 14, n.6,p. $218-241,2019$.

PS genre by applying the same rhetoric of self-promotion that intertwines past, present, and future used by US American applicants:

(PS4")

When the lack of opportunity tried to balk my future, I created my own opportunities. For example, during my freshman year, I discovered Brazil Youth Ambassadors, but could not apply for it because I did not speak English. However, I could not let this hurdle prevent me from progressing. I gathered all the resources I could online and became fluent within three years. Eventually, I applied to the program and was admitted along with 49 students from a competitive pool of approximately 13,500 candidates from all over Brazil. [...]

Now, I am aware that opportunity is only one factor among a myriad of others that also play a role in our societies' dilemmas. This realization instigated me to discover in college what these factors are through the development of research, contact with people from diverse backgrounds and exploration of varied academic fields. That is why I want to attend an American university where I will have access to all these resources. Ultimately, I will use all the skills I gather and contribute to the development of a less violent society in which one has the opportunity to arrive anywhere regardless of where one comes from.

Here, the essay projects a representation of the obstinate character of the student by contrasting the adversity he faces in Brazil with his firmness of purpose. Moreover, the writer articulates the path that brought him to the time of application around an evidence-based argument ("For example..."). By approaching the subject of the essay in such a logical way, he appeals to logos, treating the audience of readers as rational people (DEVITT; REIFF; BAWARSHI, 2004, p. 70), meeting an important requisite of PS writing. Accordingly, one of the admissions officers participating in Warren's (2013) study stated the following about a particular essay: "This is a good example of making an assertion and then backing it up with specific support. He could have just told me [...], but instead he showed me. [...] In other words, [he] makes an argument" (p. 52).

In the second paragraph of the excerpt above, the Brazilian applicant completes the aforementioned line of reasoning by pointing into the future, regarding it as a logical, reasonable goal ("That is why I want to attend an American university"). Especially relevant to this rhetorical move is the somewhat paradoxical overtones of the prepositional phrase "in our societies' dilemmas:" if, on one hand, the possessive adjective 'our' brings the writer and audience together, on the other hand, the use of the plural form of 'societies' indicates their belonging to two distinct societies, the Brazilian and the US American. This establishes opposition dynamics within the essay: the writer 
REVISTA X, Curitiba, volume 14, n.6,p. $218-241,2019$.

contrasts "the lack of opportunity" in his immediate environment with his grit to overcome it ("I could not let this hurdle prevent me from progressing"). At the same time, it links the candidate's determined ethos with the US American academic environment ("where I will have access to all these resources").

As we looked at PSs written by US American students earlier in this paper, we were able to verify their efforts to persuade an admissions committee that they already possessed the experience and resources necessary for a successful professional, social, and academic life, which they presented as an extension of their current lives as accomplished high school students. In the PSs of Brazilians to which I had access, this same self-promotional line of argumentation usually intertwines with the overcoming of great socioeconomic barriers in search for an education abroad experience, in which these students envision their future selves as fully developed individuals. The PS discussed below offers good additional examples of linguistic and discursive strategies used to carry out this rhetorical move:

(PS5')

I like to compare life to a jigsaw puzzle. We are constantly looking for pieces to complete the inside of our borders, which are the values we define as our guidelines. While looking at my story, I learned that my community, Capão Redondo, had an essential impact on the way I pieced my life's puzzle together. The adversities I faced in Capão Redondo ultimately inspired the persistence I needed to overcome challenges and define my own values.

The interpersonal approach taken by the writer from the start promotes the audience's immediate engagement: by switching between the use of the first person singular (I, my) and plural (we, our), the writer integrates the imagined addressees into the discourse as if they were somehow coauthoring: "the values we define as our guidelines" $\rightarrow$ "my own values." This Brazilian applicant also highlights the transformative nature of his socioeconomic environment and personal circumstances in preparing him for his future affiliation with the (still imagined) US American academic world. In fact, the word 'community' is used more than once to refer to the student's neighborhood, Capão Redondo, which has the largest concentration of favelas in the state capital of São Paulo:

(PS5")

During the '90s, the UN considered Capão Redondo one of the most dangerous neighborhoods in the world. [...] Drug trafficking, poor educational opportunities and, most notably, lack of dreams plague the community and create an environment where bad influences prevail. 
REVISTA X, Curitiba, volume 14, n.6,p. $218-241,2019$.

Surrounded by such an atmosphere, I realized early on that only perseverance would allow me to find the right pieces to expand my puzzle.

In 2010, I was awarded a scholarship to one of the best private schools in São Paulo through ISMART, an NGO that invests in talented young students. The school's labs, pools and gyms contrasted significantly with the poor infrastructure of my previous school [...]. Against all odds, I flourished in this newfound environment and in the process, found a new set of puzzle pieces with which to work.

This excerpt is permeated with words with negative connotations or sentiments ("dangerous," "poor," "lack," and "plague"), which are far from common in the US American applicants' essays, who give priority to discussing their best qualities and life experiences. Here, the Brazilian candidate contrasts the "bad influences" of his native environment with his perseverance to resist the determinism that threatens to thwart his plans. The underlined parts of the second paragraph above mark the self-promotion rhetoric also found in PSs written by US American students. Here, however, the Brazilian student finds himself faced with the additional need to argue that despite his humble origins, he is fully able to adapt to new surroundings wherein he could be considered an inapt foreigner: "I flourished in this newfound environment." He makes a point of reinforcing this point later in the essay:

(PS5"')

Although this school offered unique academic opportunities, it also provided a new social challenge. [...] While private chauffeurs drove my peers to school, I faced a two-hour long bus ride every day. As time passed, however, I adapted to that world and learned how to balance the contrasts between the two opposing realities I lived in.

With the adversative logical connectors shown in bold, the writer situates his adaptability in the foreground to strengthen his candidacy to an US American institution where intercultural challenges similar to those faced by him in a private Brazilian school are expected. That is, he is not only aware of his "international candidate" status, but he also presupposes the need to justify such a position and likely to avoid any preconceived notions about his nationality being used to question the intercultural competence that his PS seeks to promote. As pointed out above, the fundamental purpose of a PS is for the addressees to adhere to the writer's ethos: values, goals, and beliefs among other traits whose projection is by no means easily controllable by the college applicant. Therefore, to fulfill the purpose of the genre, the author of a PS should strike a balance between the projection of an intended image and the possible effects of this image on the sensibility of the presumed readers. 
REVISTA X, Curitiba, volume 14, n.6,p. $218-241,2019$.

In attempting to direct the interpretation of his PS-and of the ethos that it projects of himself-this Brazilian candidate goes beyond demonstrating his fluency and efficiency in the use of the English language: he shapes his utterances to a specific writing task. Thus, he reveals the rhetorical flexibility that allowed him to make a good case for his alignment with the imagined expectations of a foreign office of admissions. According to Lu (2004), such successful examples of written composition show how "individual users shape and are reshaped by the texts they produce. They are shaped by and reshape the realities of their lives" (p. 28). In other words, the ways in which writers use genre knowledge to perform social actions point to the "dialogic overtones" (BAKHTIN, 1986) of an intimate association between their perceptions of themselves and of their interlocutors both in the realm of reality and in the realms of what is possible or imaginable.

\section{CONCLUSION}

In this paper, I have discussed a rather unfamiliar genre of writing in the Brazilian context: personal narratives known in the English-speaking context of college admissions as personal statements. I examined a number of rhetorical resources that US American and Brazilian students admitted to US American universities have applied to the high-stakes task of composing an argument-driven yet personal piece of writing (logos) that conveys a credible "voice" (a discourse-based ethos) while addressing the sometimes unclear expectations of imagined readers/evaluators (pathos).

My main claim has been to show that Brazilian applicants are at a disadvantage in relation to their US American counterparts in regard to the knowledge of genres that are common in the English-speaking academic scene but that are virtually unknown to most Brazilian students by the time they start aspiring to higher education abroad. This justifies the need for studies such as the one reported here that describe and interpret the rhetorical features of genres that students need to acquire if they are to move forward in the current globalized university system.

My analysis reveals the need for writers to establish an interpersonal bridge between their formative paths and goals (ethos) and the values of the target academic community, as it is discursively constructed as the imagined receiving end (the pathos) of the genre. The excerpts of PSs presented here provide evidence showing that the personal statement is in fact an argumentative genre. Therefore, college applicants, 
REVISTA X, Curitiba, volume 14, n.6,p. $218-241,2019$.

similar to all writers in all other writing situations, should consider the broader sociocultural context in which they produce their utterances. Equally important is considering the effects of their rhetorical choices (such as arguments, words, themes, and compositional structures) on the discursive representations that they convey of themselves and, thus, on the relationships they forge with their audiences.

Additionally, the analysis reveals a number of similarities in the ways that both groups of applicants present their backgrounds and argue for their fitness for a college experience in English-speaking academia. Nonetheless, I have identified distinctive rhetorical strategies adopted by successful Brazilian applicants when addressing their imagined US American readers. These student writers face the extra hurdle of "translating" their local realities-both metaphorically and literally-to the language and the culture of their foreign interlocutors. In a way, more than setting Brazilians aside from US American candidates, the intercultural issues that the former must address when creating a PS in English reaffirm the codetermination of ethos and pathos in the fulfilment of the communicative purpose of discourse genres and, hence, the fundamental importance of adjusting one's language to different genres and scenes.

\section{REFERENCES:}

AMOSSY, R. (Org.). Imagens de si no discurso: A construção do ethos. São Paulo: Contexto, 2005.

BAKHTIN, M. M. Speech Genres and Other Late Essays. Trans. Vern W. McGee. Eds. Emerson and Michael Holquist. Austin: University of Texas Press, 1986.

BAWARSHI, A.; REIFF, M. Genre: An introduction to history, theory, research, and pedagogy. Fort Collins: The WAC Clearinghouse, 2010.

BROWN, R. M. The rhetoric of self-promotion in personal statements. Dissertation (Doctor of Philosophy in Rhetoric) - Department of Rhetoric and Writing. The University of Texas at Austin, 2005.

DEVITT. A. J.; REIFF, M.J.; BAWARSHI, A. Scenes of Writing: Strategies for composing with genres. New York: Pearson, 2004.

DING, H. Genre analysis of personal statements: Analysis of moves in application essays to medical and dental schools. English for Specific Purposes, v. 26, n. 3, 2007, p. 368-392.

DITTRICH, I. J. Por uma retórica do discurso: Argumentação técnica, emotiva e representacional. Alfa, v. 52, n. 1, 2008, p. 21-37. 
REVISTA X, Curitiba, volume 14, n.6,p. $218-241,2019$.

EARLY, J. S.; DECOSTA-SMITH, M. Making a case for college: A genre-based college admission essay intervention for underserved high school students. Journal of Writing Research, v. 2, n. 3, 2011, p. 299-329.

FIORIN, J. L. Argumentação. São Paulo: Contexto, 2015.

HYLAND, K. Metadiscourse in academic writing: A reappraisal. Applied Linguistics, v. 25, n. 2, 2004, p. 156-177.

Metadiscourse: Exploring Writing in Interaction. London: Continuum, 2005.

JOHNS, A. Genre awareness for the novice academic student: An ongoing quest. Language Teaching, v. 41, n. 2, 2008, p. 237-252.

KANNO, Y.; NORTON, B. Imagined communities and educational possibilities: Introduction. Journal of Language, Identity, and Education, v. 2, n. 4, 2003, p. 241-249.

LU, M. Z. An essay on the work of composition: Composing English against the order of fast capitalism. College Composition and Communication, v. 56, n. 1, 2004, p. 16-50.

MAINGUENEAU, D. Analyzing self-constituting discourses. Discourse Studies, v. 1, n. 2, 1999, p. 175-199.

Analysis of an academic genre. Discourse Studies, v. 4, n. 3, 2002. p. 319-342.

MARCUSCHI, L. A. Gêneros textuais: Definição e funcionalidade. DIONISIO, A. P.; MACHADO, A. R.; BEZERRA, M. A. (Org.). Gêneros Textuais \& Ensino. São Paulo: Parábola Editorial, 2010, p. 19-38.

PALEY, K. S. The college application essay: A rhetorical paradox. Assessing Writing, v. 3, n. 1, 1996, p. 85-105.

POSSENTI, S. Indícios de autoria. Perspectiva, v. 20, n. 1, 2002, p. 105-124.

SAMRAJ, B. An exploration of a genre set: research article abstracts and introductions in two disciplines. English for Specific Purposes, v. 24, n. 2, 2005, p. 141-156.

SWALES, J. Genre Analysis: English in academic and research settings. Cambridge: Cambridge University Press, 1990.

Occluded genres in the academy: The case of the submission letter. Academic writing: Intercultural and textual issues. VENTOLA, E.; MAURANEN, A. (orgs.). Amsterdam: John Benjamins, 1996.

VIDALI, A. Performing the Rhetorical Freak Show: Disability, Student Writing, and College Admissions. College English, v. 69, n. 6, 2007, p. 615-641.

WARREN, J. The rhetoric of college application essays: Removing obstacles for low income and minority students. American Secondary Education, v. 42, n. 1, 2013, p. 4356. 